\title{
Vision and Market Segmentation in Urban Strategy through Marketing Approach: A Case Study of Sumy City
}

\author{
Anastasiia YEZHOVA \\ $\mathrm{PhD}$ student, National University of Public Service \\ Doctoral School of Public Administration Sciences, Budapest, Hungary \\ e-mail: yezhova.nastya@gmail.com
}

\begin{abstract}
Competition for all kinds of resources has started among the Ukrainian cities and first of all for human capital. Therefore, a proper strategic planning is the uppermost priority for local governments. In this paper, the vision and market segmentation of the adopted strategy for the socio-economic development of the Ukrainian city of Sumy is analysed using the comparative method and content analysis. It aims to demonstrate that the city marketing approach towards strategy creation helps to make the strategy more concrete and visible. Existing city marketing strategies of Helsinki, Whitehorse, and North Port were used for comparison.
\end{abstract}

Keywords: urban strategy, city marketing, vision, market segmentation, target audience

\section{Introduction}

The main issue for the Ukrainian municipalities these days is their inability to comprehend how they are losing an enormous amount of human resources. Moreover, it is still not clear for them that competition for all kinds of resources has already started both inside and outside the country. A low standard of living and ongoing military conflicts make people search for higher-income opportunities. According to the Ministry of Social Policy of Ukraine, the number of Ukrainians who are permanently employed abroad is 3.2 million. This is $18 \%$ of the total labour force of the country (Вінокуров 2019).

At the same time, according to The Global Competitiveness Index 4.0 (World Economic Forum 2019: 13), Ukraine occupies the $85^{\text {th }}$ position among the total of 141 countries. It is the least competitive state after Moldova among the neighbouring countries. By competitiveness, we mean the country's productivity, which eventually leads to economic growth and the rise of human well-being (Cann 2017). 
After the decentralization process and budgetary reform in 2015, Ukrainian cities received more resources and, consequently, power in determining their future (for comparison, the development budget of Sumy city for 2013 was 60 million UAH, and for 2016 it increased to 600 million) (Корнієнко 2020). Therefore, the municipality should have a clear vision of city marketing and development strategy in order to raise the city's competitiveness level. The attractiveness and investment potential of the settlement can and must be distributed by the efforts and cooperation of the local public administration and all the stakeholders.

\section{Objective and Methodology}

The objective of the paper is to demonstrate that the city marketing approach towards strategy creation, which includes market segmentation, helps to make the strategy more concrete and visible.

Research questions:

- Does city marketing strategy have a clearer semantic kernel than the socioeconomic one?

- Does the city marketing approach in strategy planning assist in detailed market segmentation and help to avoid generalization?

To answer the questions of the research, it was decided to analyse vision array and market segmentation in the developed and adopted strategy aimed at the socioeconomic development of the city of Sumy. This is carried out with the help of content analysis of the strategy's vision and comparison of market segmentation with others in the city marketing strategies. The possibility to compare socioeconomic strategies with city marketing ones is justified by the common intended output of both types of strategies: human well-being.

To analyse the vision of the strategies, the method of content analysis was chosen (Брянцева 2010: 69-81). A good example of content analysis of the strategies was observed in the article of Bokeriya S., Kerner E., and Kuznetsova D., Analysis of Russian and US Arctic Strategies, the methodology of which was chosen as a benchmark.

The indicator of the analysis is the frequency of the words. The online tool Advego is used for this purpose, as it automatically counts (the most frequently used) keywords in the provided text. The keywords are grouped by the author according to their meanings, e.g. words like 'space', 'neighbourhood', and 'access' belong to the group 'Infrastructure and urban planning'; 'Target group' includes such words as 'community', 'locals', 'students', etc. This grouping gives an understanding of the main strategic focus of each city. It can also be called a definition of the text's semantic kernel. 
The comparison will be made in a cross-sectional framework, where target audiences in the cities' strategies will be compared. The benchmark city marketing strategies were selected by the author and include Helsinki, Whitehorse, and North Port. The chosen cities vary in the amount of population, geographical location, and level of economic development. Nevertheless, the choice is explained by a swell in population and the forecast of its further growth in these cities, which gives reason to consider the strategic planning of their local governments as effective and efficient.

\section{Limitations of the Research}

In the present research, the author does not analyse the strategies in their entirety but only the vision array and parts carrying information on the target groups. Therefore, the results of the comprehensive content analysis (semantic kernel), of the whole strategy would be different and lead to different conclusions.

\section{Sumy's Economic Profile}

There are nine economic regions in Ukraine. The city of Sumy is part of the Northeast Economic Region, which consists of the Poltava, Sumy, and Kharkiv administrative regions (Figure 1). The most developed industries of the Northeast Economic Region are mechanical engineering and metalworking, a significant share of which falls to the military-industrial complex. The second and third places are occupied by the consumer and food industries respectively, followed by the chemistry, petrochemistry, and building materials industry.

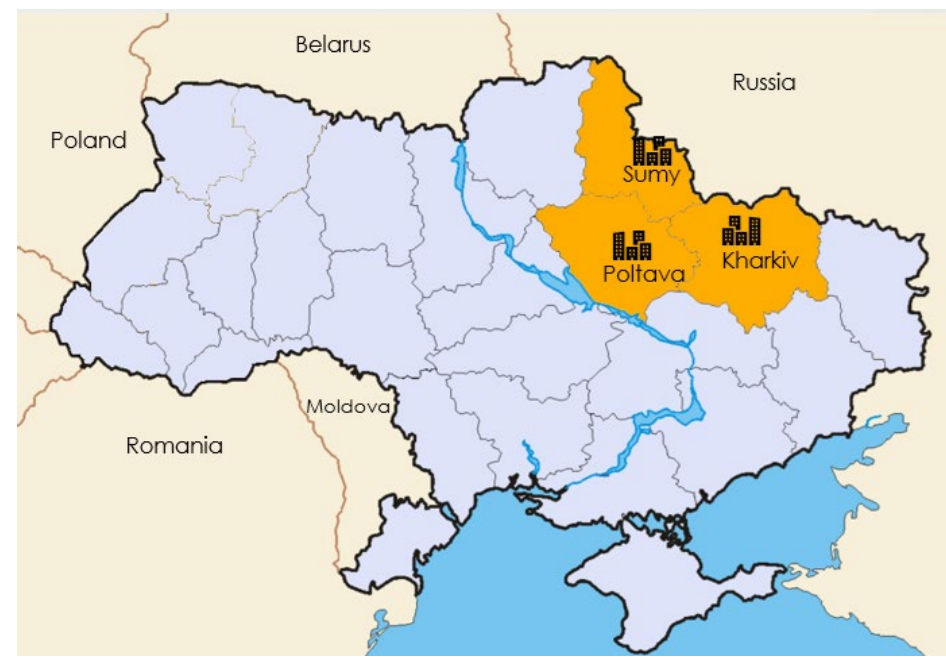

Source: uk.wikipedia.org and own inscriptions

Figure 1. Northeast Economic Region of Ukraine 
Currently, the main problem for this economic region is the long border (over 600 $\mathrm{km}$ ) with the Russian Federation. The military conflict in the Donbas region and the annexation of Crimea in 2014 became governing factors of the deterioration of trade relations. Moreover, it is considered to be a potential zone for further conflict development. Sumy is a regional centre of the Sumy Region located in the northeastern part of the country. The population of the city is above 250,000, of which 100,000 constitute the labour force (40 per cent of the population). In addition, 30,000 students live in the settlement (12 per cent).

There are 3,050 active enterprises on the territory of the city: 4 large, 136 medium-sized, and 2,910 small. They include Concern Nicmas (manufacturer of drill collars and pipes), Sumy NPO (manufacturer of machinery and equipment for special purposes), Kusum Pharm (producer of pharmaceuticals), Limited Liability Company (LLC) 'Horobyna' (producer of alcoholic beverages), etc. There is also an economic cluster specialized in the manufacturing of packaging materials and closures, which is composed of LLC 'Gualapack Ukraine', LLC 'Guala Closures Ukraine', and the joint-stock company 'Technologia' (Invest in Sumy, 2020). The latter one is the leader among the Sumy enterprises in products sold for export. Throughout 2018, enterprises products sold and services for UAH 51.3 billion (EUR 1.5 billion) (Сумська міська рада 2019).

In 2019, the city council approved Sumy Development Strategy 2030. In the foreword, the mayor of the city, Oleksandr Lysenko, mentioned the state of competitiveness among settlements, which carries hope for the switch in the local government's vector of development: 'After all, everyone understands perfectly well that in the XXI century we are competing not only with cities within Ukraine, we are competing with the whole world. Therefore, it was important to properly formulate our priorities, strategic and operational goals' (Сумська міська рада 2019). ${ }^{1}$

The methodology of strategy creation was developed by the European Union as an instrument of development strategy planning and implementation (the researched strategy does not provide reference to the methodology description). It included opinion surveys, strategic sessions, and public hearings.

The strategy's paragraph on the investment potential of the city includes information on the project Сумський Бізнес Хаб (Sumy Business Hub). It intends to help entrepreneurs to cooperate, study, and exchange knowledge and experiences. The Hub has no website and can be accessed exclusively through its Facebook group. This project was created under the guidance of Sumy State University, what also explains the presence of the University's programme promotions in the news feed of the group. The researcher contacted eight owners of small businesses in Sumy, and none of them has ever heard about this project nor participated in its programmes.

In April 2020, the Antimonopoly Committee of Ukraine agreed on the allocation 
of cc. UAH 39 million of state funding over five years for the development of the Sumy Industrial Park territory (Figure 2), a concept already approved by the city council of Sumy (Кудлай 2020). The announced period of operation of the park is 30 years. On its territory of 17.5 ha, up to 1,050 jobs will be created according to preliminary calculations. The priority types of economic activity include the production of light metal packaging, components for cars, in particular electrical equipment and devices, the production of plastic products, and the food industry.

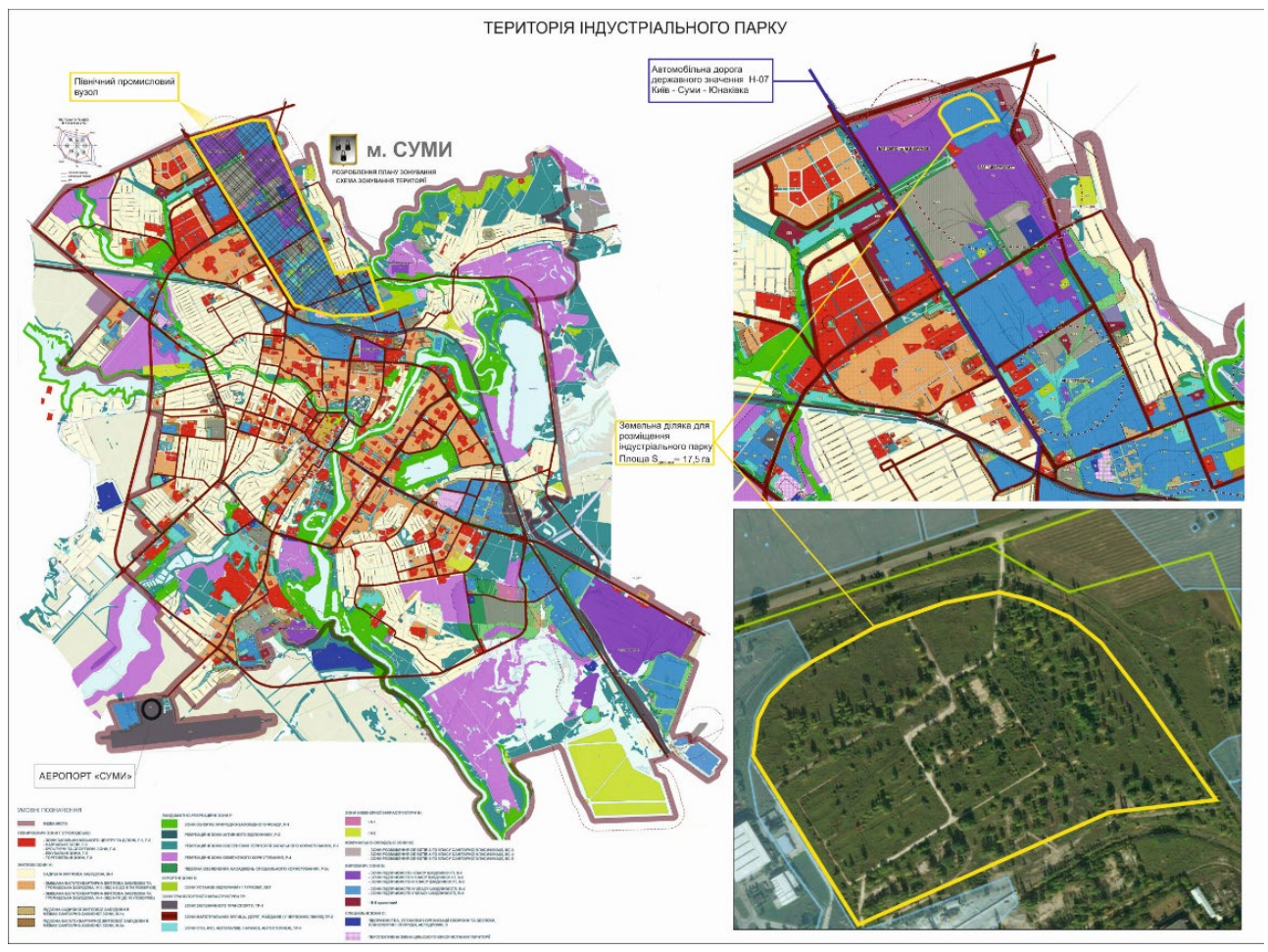

Source: www.visit.sumy.ua

Figure 2. The territory of Sumy Industrial Park

\section{Theoretical Framework: The City's Marketing Approach}

'A strategy is about being different.' Michael B. Porter

Early in this century, municipalities were perceived by citizens only as the organ of operational problem solving. Over and above, nowadays they handle the social and economic life of the city, a healthy living environment, and the welfare of the population. Local government officials as the chief executives and representatives 
of cities' interests are the first ones who have a stake in the advantages brought by strategic planning, considering that 'the role of the political personality is strengthening' (Kis 2018: 84).

The overall success of the settlement directly depends on its economic prosperity. Therefore, urban development strategies always include an increase in direct foreign investments based on competitiveness, the creation of a sustainable environment, the construction of a strong local society, the support of high export of the local producers, etc. Lately, cities have started to create not only general development strategies but also marketing ones.

First, Martin Boisen brings up the question of a theoretical duality of city marketing, as scientists and practitioners have a different approach to it: 'A scientist looks at city marketing as a specific way in which cities react to a perceived state of inter-urban competition, whereas a practitioner looks at city marketing as a specific tool-box from which specific managerial practices can be employed' (Boisen 2007: 8).

Practitioners in the US have used city marketing since the $19^{\text {th }}$ century (Ward 1998: 27-28). At that time was the visual identity of New York made ('I Love NY'). In 1990, the fundamental work of G. Ashworth and Jan Hendrik Voogd, Selling the City: Marketing Approaches in Public Sector Urban Planning, was published; the authors were one of the first who focused on the development and promotion goals of European cities. In 1992, J. van der Meer published his work The Role of City Marketing in Urban Management, in which the city was presented as a product offered to the target groups. Therefore, from a conceptual point of view, city marketing turned out to be the closest to the sociology of rational choice.

The work Broadening the Concept of Marketing by Kotler and Levy (1969) created the very first theoretical concept of place marketing and proposed to imply the marketing concept to non-business entities as well. As Gabriela Cecilia Stănciulescu hits the mark later: 'Marketing should not be exclusively the advantage of the private sector' (Stănciulescu 2009: 115).

After the place marketing concept had spread around the world, a lot of cities implemented it into their policies. In most cases, the concept was narrowed to the visual place branding (creation of logos and slogans) and promotion activities. The latter, as a rule, had a single goal - city visual brand awareness. But it goes far beyond and comprises economic, social, infrastructural, etc. dimensions. Above all, the so-called 'waste strategies' became a widespread phenomenon (Metaxas 2005: 49). They are made mostly for the sake of appearance and are partially implemented with no evaluation whatsoever.

Using a general simplified definition of strategy as a detailed plan for achieving success (Cambridge University Press), the author aims to adhere to the idea of its universal nature. The public sector started to borrow the managerial approaches from the business field in the 80s and the 90s - the scientific literature calls it new public management. It was an effective response to the crisis of the bureaucratic 
administration model in many countries (Osborne-Gaebler 1992). Alongside performance measurement and result-oriented attitude, public administration began to plan with a long-term perspective. At the same time, we should not disregard the major difference between the goals of business strategy and the urban one. In the first case, companies see the result in the profit, whereas in the second case this is wellbeing (it is a direct consequence of superior economic performance). It causes huge difficulties in the evaluation of city strategies and their effectiveness considering the complexity of the 'welfare' concept and its numerical representation.

One of the most widespread ideas in business strategic planning belongs to Michael B. Porter. To sum up his keynote speech on strategy held at the event organized by the Institute for Competitiveness in India, the worst mistake one can make in terms of strategy is attempting to compete with rivals on the same dimension (Keynote on Strategy by Michael Porter, professor, Harvard Business School, 2017). In the 'urban world', it is impossible to be 'the best' among the cities - even considering the existence of various ratings - because each settlement serves its own audience and has its unique structure. The components of the city's audience are quite similar: residents, businesses, migrant workers, students, investors, and tourists (in some particular cases, we can add patients if the city is famous for its therapeutic potential). In each case, the profile of the resident or the investor will be different, and, therefore, it is necessary to conduct research and clearly understand who you serve. The only way to be 'the best' is to compete with your performance evaluation by your target audiences over the years.

The above idea can be supported by Erik Braun's integrated approach to city marketing: 'the core idea of marketing is to think in terms of wants and needs of the (potential) customers'. Thus, the philosophy of his work introduced the societal marketing concept based on city marketing; so, it may be called customeroriented. Therefore, it is not only about infrastructure, urban planning, or economic development, but it is first about people, their needs and demands.

From another point of view, not every stakeholder is competent enough regarding strategic management or urban development issues and, therefore, cannot effectively influence the process. This approach can equal a national vote. It is fair enough to state that the majority of the society is not educated in political and social sciences, but this does not give grounds for depriving them of a voting right. It is an archaic way of thinking and has nothing in common with today's civic engagement and breakthrough in the equality of humans.

To sum up, the core function of city marketing is to identify and analyse the expectations of target groups regarding their settlement and to assess the possibilities of their satisfaction with actual resources. 


\section{Structure and Content Analysis of Vision in the Selected Strategies}

The Institute for Housing and Urban Development Studies defines strategy vision as 'a dream or picture of what the city wants to look like in the future to achieve its potential. A vision is the overall image of what the community wants to be at some point in the future.' The main accent should be made on the presence of 'community' in the provided definition and the importance of its participation in all stages of planning (Institute for Housing 2017).

In Table 1, the semantic kernel of four strategies is presented, which consists of the most frequently used words (keywords) and/or phrases in the text. The author introduces the first seven keywords in Table 1.

In the case of Helsinki (population c. 630,000), the capital of Finland, we can see that 'indicator' becomes the most widespread word, which along with the word 'performance' shows us the importance of further analysis of the strategy performance and effectiveness (Brand New Helsinki 2016). For example, if we look at the objective 'build our future vision and strengthen local pride', the performance indicators consist of image surveys with residents, usability assessment of marketing tools, and media monitoring. Marketing strategy evaluation remains the most difficult stage in the strategy 'lifecycle', wherefore it is necessary to define the evaluation mechanisms during the planning phase.

Whitehorse is a Canadian city located in the Yukon Territory (population c. 27 thousand). The semantic kernel of its strategy ('community', 'citizen', 'government') highlights the community-oriented approach of the document and mostly belongs to the 'target group' (City of Whitehorse Marketing Strategy 2013). We can also see a huge emphasis on 'access', what can be explained by the remote location of the city from the most vivid (culturally and economically) Saskatchewan, Alberta, Ontario, and Quebec provinces and also by a relatively small population. As noted before, Sumy faces the same geographic situation, and it has likewise listed 'accessibility' among the major points.

The strategy of the American city of North Port, Florida State (population c. 69 thousand) concentrates on community and its values ('target group'), planning and branding (2011-2013 Strategic Marketing Plan City of North Port, Florida 2011). The brand promotion was made part of the marketing strategy, where the community element shows the importance of 'brand ambassadors' (usually locals who share the positive messages about the settlement).

The case city of the article, Sumy, shows the most neutral semantic kernel, where the 'target group' is outside the kernel, but it still prevails in the marketing strategies. Meanwhile, 'economics' appeared for the first time in this research as a keyword. The conclusion can be made that the creators of Sumy's strategy see economics in and of itself as a source of its improvement, while in other strategies 
collaboration with the community, accessibility, and brand are considered to be some of the basic layers of economic development. Above all, in Sumy's strategy alone, two adjectives became part of the vision's semantic kernel.

Table 1. Semantic kernel of the strategies

\begin{tabular}{|c|c|c|c|c|}
\hline City & Title of the vision array & $\begin{array}{c}\text { Number of } \\
\text { symbols }\end{array}$ & Semantic kernel & Grouping \\
\hline \multirow{7}{*}{ Helsinki } & \multirow{7}{*}{$\begin{array}{c}\text { City marketing } \\
\text { objectives and } \\
\text { performance indicators }\end{array}$} & \multirow{7}{*}{5,281} & indicator & Evaluation \\
\hline & & & business & Target group \\
\hline & & & event & Promotion \\
\hline & & & marketing organization & Planning \\
\hline & & & performance & Planning \\
\hline & & & development & Evaluation \\
\hline & & & & Planning \\
\hline \multirow{7}{*}{ Whitehorse } & \multirow{7}{*}{$\begin{array}{c}\text { Objective hierarchy } \\
\text { and market positioning }\end{array}$} & \multirow{7}{*}{6,234} & access & Infrastructure \\
\hline & & & community & Target group \\
\hline & & & citizen & Target group \\
\hline & & & government & Target group \\
\hline & & & space & Infrastructure \\
\hline & & & value & Neutral \\
\hline & & & wilderness & Promotion \\
\hline \multirow{7}{*}{ North Port } & \multirow{7}{*}{$\begin{array}{l}\text { Focus, objectives, and } \\
\text { goals }\end{array}$} & \multirow{7}{*}{3,405} & community & Target group \\
\hline & & & marketing & Research \\
\hline & & & plan & Planning \\
\hline & & & brand & Promotion \\
\hline & & & strategy & Planning \\
\hline & & & help & Neutral \\
\hline & & & community values & Target group \\
\hline \multirow{7}{*}{ Sumy } & \multirow{7}{*}{ Vision and mission } & \multirow{7}{*}{11,618} & development & Planning \\
\hline & & & governance & Planning \\
\hline & & & life & Neutral \\
\hline & & & economics & Neutral \\
\hline & & & necessary & Neutral \\
\hline & & & level & Neutral \\
\hline & & & effective & Neutral \\
\hline
\end{tabular}

Source: own elaboration

\section{Market Segmentation}

As K. Rozhkov points out quite accurately, answers along the line of 'city for people' to the question 'For whom is the city?' will not be sufficient for a marketer (Рожков 2015: 84). Marketing practitioners need a detailed market segmentation to plan as precisely as possible and meet the needs of various consumers. 
Market segmentation is one of the main features of city marketing strategy. It divides the entire consumer market into groups so as to be able to communicate with them and meet their specific wants and needs. Like in the business world, you must know who your (potential) buyers are.

According to Kotler et al. (1993: 21-27), the city's target audiences include visitors, residents, and working population, enterprises and industries and the foreign markets. The most detailed classification of city marketing target groups is proposed by I. Tózsa (2011: 19-20). They include the local population, managers (operators), investors, migrant workers, university students, patients, and tourists. It is important to mention that the order of the groups presented above is structured by the priority principle. The local population is always the first to satisfy, as they are an inevitable part of the city's competencies. The fact that managers occupy a higher position than investors is explained by the communication process between them. The managers are the people who work as 'filters' for the decision makers. Their subjective perception of the place undoubtedly influences the report and presentation of the location to the investor.

In this work, we will operate with the following target audiences of the city:

1) Local population (residents, locals, citizens): people who permanently reside in the settlement, usually work and pay taxes (does not refer to the underaged and elderly population). The author would like to raise the question for further research as to whether the fact of not paying taxes excludes homeless people from the 'local' group. In this study, we will not do that, guided by the concept 'right to the city' of H. Lefebvre. Some practitioners also make a distinction between low-cost and high-cost residents: low-cost are those people who provide a net profit for public revenues, and high-cost are those who consume more social services than they pay in taxes and fees for using public services.

2) Business owners: people, mostly residents, who have officially registered enterprises in the city and who pay taxes.

3) Investors: can be city locals or outsiders who are interested in a range of investment capabilities, e.g. investing in the development of the settlement and/or its enterprises, buying real property or municipal bonds, etc.

4) Managers (operators): employees of investors, whose obligations include collection of information, report preparation, analysis of the prospective investment projects and their evaluation. Managers are important for the city because their perception of the place and their conclusions about it directly influence the decision-making process of the investor.

5) Migrant workers: people who are employed in the city but reside in a different settlement. As a rule, this type of workers commutes daily.

6) Students: people who study at the educational institutions located on the territory of the settlement. Institutions include not only universities but boarding schools (e.g. sports), vocational training schools, conservatories, etc. 
7) Tourists: short-term or long-term visitors of the city who reside in another settlement. The purposes of their visit can vary from sightseeing and event attendance to business.

8) Patients: visitors of the city who arrive with the purpose of medical treatment or check-up. This group is especially important for the places with unique treatment facilities (for example, Budapest is rich in thermal water, or Istanbul and Seoul, which are famous for plastic surgery facilities).

The importance of thorough market segmentation is explained by the different demands of the target audiences. It goes without saying that some demands can overlap. For example, each target group is interested in a safe and clean environment.

There are three types of segmentation strategies: concentrated, differentiated, and undifferentiated (Ashworth-Voogd 1988). The first type of strategy concentrates on one target group, the second one is focused on several groups, but it has a tailored approach to each of them, and the third one also encompasses more than one target audience - nevertheless, it has a 'one size fits all' approach.

In Table 2, we can see the target audiences defined in each researched strategy. The cities of Helsinki, Whitehorse, and North Port simultaneously outline residents and tourists as their customers. Whitehorse's strategy is the narrowest one in the sense of targeting, as far as it is explained by the limited resources and attempt to focus on the most important customers. Helsinki defines very peculiar target audiences such as potential start-uppers or business decision makers, who usually make part of a 'business' or 'investor' audience. Nevertheless, it gives the researcher a reason to expand Tózsa's list of the target group and add start-uppers as a unique group, which combines features of innovators, businesspersons, and potential investors. North Port has the most classical but short market segmentation (explained by the absence of 'students', 'investors' and their 'operators'). However, the author does not agree with the definition of the 'stakeholders' group, as stakeholders of the city - according to Freeman and Reed - are the residents, the government, and the business sphere. In other words, the stakeholders are the members of the entity, whose support and activities make it functional. Therefore, without them, the entity ceases to exist (Freeman-Reed 1983: 88-106). In the case of North Port, the stakeholders were limited to municipal officials and staff and community organizations.

The situation is more interesting with Sumy's development strategy, as there is no concrete market segmentation, but there is the repeatedly used term 'concerned parties' (in Ukrainian: зацікавлені сторони). Keeping in mind that stakeholders are a synonym of the latter, it is to be substituted hereafter. According to the strategy, stakeholders include city council representatives, business associations, universities, and the civilian sector. Interestingly, each target group is perceived as an institution ('university' instead of 'student', 'business association' instead of 'business owner'), which gives grounds for talking about the institutionalization of Sumy's political decision-making processes. It contradicts current global practices 
when central and local governments go beyond the ‘institution-based approach' in governance and prioritize interpersonal communication.
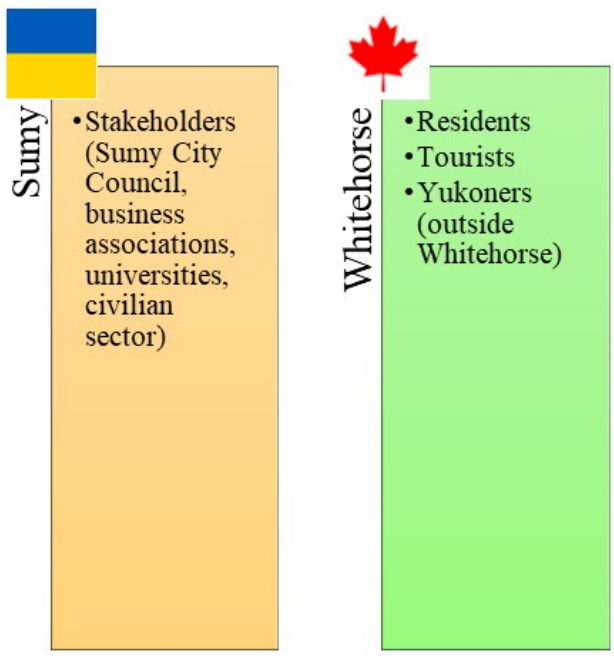
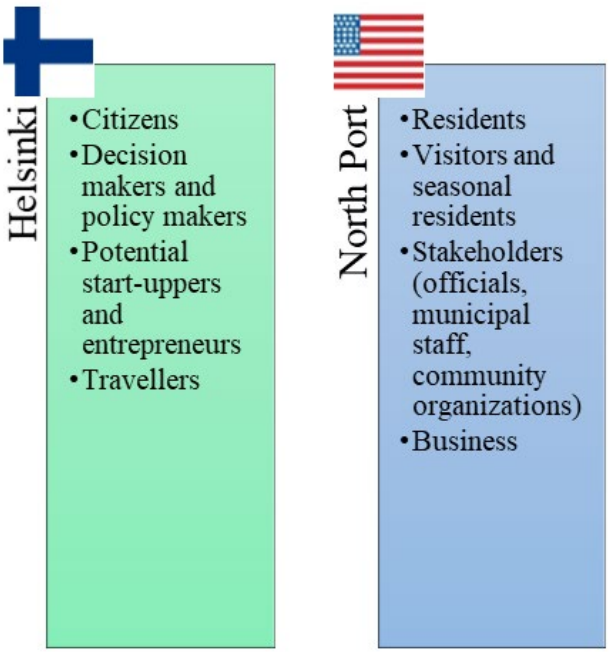

Source: own elaboration

Figure 3. Target groups of the researched strategies

\section{Conclusions}

1. The visions of Sumy's socio-economic development strategy are vague. The semantic kernel of the vision array within the strategy does not provide a clear understanding of the strategy's focus and goals. It allows presuming that a strategy consists of a standard set of phrases and does not tackle specific problems of the city or take up challenges compared to Helsinki (start-up, business, event management) or Whitehorse (accessibility). The strategies created with the city marketing approach have a more specific semantic kernel than the ones without it.

2. As regards target audiences addressed in Sumy's strategy: they are considered as institutions but not as individuals, which gives grounds for talking about the institutionalization of governance and the generalization of the terms as a counterbalance to a customer-oriented approach. It makes the target groups of the strategy not explicit. The presence of clearly defined target groups in the researched city marketing strategies influences the content of the document and makes it sounder and more valid. The categorization of the city's customers provided by Kotler and Tózsa does not correspond to the groups addressed in Sumy's strategy.

3. Ostensibly, Sumy's development strategy does not pay much attention to the city's target audiences and accountability towards them. It is logical to turn 
stakeholders into partners, but it is mistakenly understood that partnership is about compliance. A partnership has to be reciprocal and built on lasting cooperation, not only on the stage of creation. It is crucial to set objectives of the city's development that are supported by target groups. This support is vital for the long-term success of the strategy. Therefore, it is recommended that stakeholders' participation in the implementation of the strategy has a place in the vision formulated in the document.

In conclusion, strategies created through the marketing approach (Helsinki, Whitehorse, and North Port) have a clearer focus on vision and detailed market segmentation, which makes the document more intelligible and achievable.

\section{References}

ASHWORTH, Gregory John-VOOGD, Henk. 1988. Marketing the City: Concepts, Processes and Dutch Applications. The Town Planning Review 1(59): 65-79. 1990. Selling the City: Marketing Approaches in Public Sector Urban Planning. BOISEN, Martin 2007. The Strategic Application of City Marketing to Middle-Sized Cities. Utrecht: Utrecht University.

BRAND NEW HELSINKI. 2016. The City of Helsinki Marketing Strategy 20162020, April 22. Available at: http://www.brandnewhelsinki.fi/2020//app/ uploads/2016/07/02_Helsinki_strategia_ENG_web.pdf.

Cambridge University Press. (n. d.). Cambridge Dictionary. Meaning of Strategy in English. Available at: https://dictionary.cambridge.org/dictionary/english/ strategy.

CANN, Oliver. 2017. What Exactly Is Economic Competitiveness? September 27.

Available at: https://www.weforum.org/agenda/2017/09/what-is-economiccompetitiveness/.

CITY OF WHITEHORSE MARKETING STRATEGY. 24 December 2013.

Available at: https://www.whitehorse.ca/home/showdocument?id=4090.

FREEMAN, Edward-REED, David. 1983. Stockholders and Stakeholders: A New Perspective on Corporate Governance. California Management Review 25(3): 88-106.

INSTITUTE FOR HOUSING and Urban Development Studies and Labor für Politik und Kommunikation. 2017. City Development Strategies 2.0 - Cities Growing with Vision. Available at: https://www.citiesalliance.org/sites/default/files/CDS_ Toolkit_Web.pdf.

INVEST IN SUMY. 2020. [motion picture].

Availableat:https://www.youtube.com/channel/UCjkmGsQOa5K3J3Q4jmC7XUQ. KEYNOTE ON STRATEGY BY MICHAEL PORTER, Professor, Harvard Business School. 2017. [motion picture]. India. Available at: https://www.youtube.com/ watch?v=EvvnoNAUPSo\&ab_channel=arthsastra. 
KIS, Norbert. 2018. Anti-Politics, Populism and Political Psychology. Comparative Politics Russia 9(2): 83-93.

KOTLER, Philip-HAIDER, Donald-REIN, Irving. 1993. Marketing Places: Attracting Investment, Industry, and Tourism to Cities, States, and Nations. New York: Free Press.

KOTLER, Philip-LEVY, Sidney. 1969. Broadening the Concept of Marketing. Journal of Marketing 1(33): 10-15.

MEER, Jan van der. 1992. The Role of City Marketing in Urban Management. Erasmus University.

METAXAS, Teodor. 2005. Market Research and Target Market Segmentation in Place Marketing Procedure: A Structural Analysis. Discussion Paper Series 11(3): 47-60.

OSBORNE, David-GAEBLER, Ted. 1992. Reinventing Government: How The Entrepreneurial Spirit Is Transforming the Public Sector. Basic Books.

PISKÓTI, István-NAGY, Szabolcs. 2007. Competence-Based View in Place Marketing. ResearchGate. 2007. Available at: https://www.researchgate.net/ publication/278784859_Competencebased_view_in_place_marketing.

STĂNCIULESCU, Gabriela Cecilia. 2009. The Role of Urban Marketing in the Local Economic Development. Theoretical and Empirical Researches in Urban Management 4(10): 114-135 . Available at: https://www.academia.edu/4202987/ the_role_of_urban_marketing_in_the_local_economic_development.

TÓZSA, István. 2011. City On Sale: An Introduction to Urban and Regional Marketing. Available at Corvinus Research Archive: http://unipub.lib.unicorvinus.hu/1958/1/IstvanTozsa_UrbanMarketing.pdf.

WARD, Stephen Victor. 1998. Selling Places: The Marketing and Promotion of Towns and Cities 1850-2000. s. l.: Routledge.

WORLD ECONOMIC FORUM. 2019. The Global Competitiveness Index 2019. (ed. by K. Schwab). Available at: http://www3.weforum.org/docs/WEF_ TheGlobalCompetitivenessReport2019.pdf.

YEZHOVA, Anastasiia. 2020. Theoretical Concept and Definition of City Marketing. In: Jesenko, E. (ed.), Public Administration and Society XXI: 121-130.

БОКЕРИЯ, Светлана-КЕРНЕР, Екатерина-КУЗНЕЦОВА, Диана. 2020. Контент-анализ арктических стратегий России и США. Власть 117-123.

БРЯНЦЕВА, Е. 2010. Контент-анализ в исследовании имиджа. Социологи 69-81.

ВІНОКУРОВ, Ярослав. 19 July 2019. Громадське Телебачення. Майже кожен 5-й українець працездатного віку перебуває на заробітках - уряд. Available at: https:// hromadske.ua/posts/majzhe-kozhen-5-j-ukrayinec-pracezdatnogo-vikuperebuvaye-na-zarobitkah-uryad.

КОРНІСНКО, Максим. 2020. Навіщо нам депутати і як вони мають пращювати. Available at: https://cukr.city/city/2020/nahiba-nam-depytat/. 
КУДЛАЙ, Е. 16 April 2020. Данкор онлайн. АМКУ согласовал выделение 39 млн грн госфинансирования на обустройство индустриального парка “Сумы”". Available at: http://www.dancor.sumy.ua/news/newsline/311585.

РОЖКОВ, Кирилл. 2015. Маркетинговый подход к изучению мегаполиса: необходимость, принципы и перспективы. Экономическая сочиология 16(3): 74-109.

СУМСЬКА МІСЬКА РАДА. 28 Deсеmber 2019. Стратегія розвитку міста Суми 2030. Available at: https://smr.gov.ua/uk/dokumenti/rozrobka-stratehii-rozvytku.html. *** 2011-2013 Strategic Marketing Plan City of North Port, Florida. 2011.

Available at: https://icma.org/sites/default/files/304085_2011-2013\%20 Strategic\% 20Marketing\%20Plan\% 20City\% 20of\% 20North\%20Port.pdf. 